\title{
Improve the Teachers' Skill in Design Learning Trough the Empowering of MGMP and the Performance Motivate
}

\author{
Alhafif Syahputra \\ Kantor Kementerian Agama, Pematangsiantar, Indonesia \\ syahputraalhafif@gmail.com
}

\begin{abstract}
The science teachers' skill in designing learning are very low in pematangsiantar. The teachers' performance motivate are also rarely measured. So far the method that used to give the instruction for teachers' are conventional method. The aim of the research to know the improvement of science teachers' skill in desaign learning through empowering MGMP and performance motivate. This is an experimental research with $2 \times 2$ factorial design. This research have done among the junior high school science teachers' in Pematangsiantar. With the total number of studied are 24 persons. The result of the research show that : 1) There are the difference the teachers' skill in design science learning with creative and copying method, 2) There are the difference of the teachers' skill. In design science learning betmeen those who hare high performance motivate with the low one, 3) There are the interaction between the guidance method and performance motivate, 4) The teacher who have high performance motivate that used the creativy method give higher scores in design science learning than used copying method, and 5) The teacher who have low performance motivate that used the copying method give higher scores in design science learning than used creativy method.
\end{abstract}

Keywords

teachers' skill in designing learning, enpowery the MGMP, performance motivate;

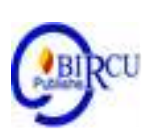

\section{Introduction}

The teaching and learning process is at the core of the overall educational process. Because the teaching and learning process contains a series of actions by the teacher and students on the basis of a reciprocal relationship that takes place in an educational situation to achieve goals. The interaction between teachers and students is the main requirement for the teaching and learning process to take place. Interaction in the teaching and learning process has a broad meaning not only the relationship between teachers and students, but educational interactions that provide scientific concepts, as well as instilling moral values in students involved in the teaching and learning process. Teacher is a position or profession that requires certain skills or competencies. A job as a teacher cannot be done by people who do not have sufficient skills. People who are good at speaking in certain fields cannot be called teachers. To become a teacher, special requirements are needed, especially as a professional teacher. Professional teachers must fully master the ins and outs of education and teaching with various other sciences that are relevant to teacher tasks.

Rahman and Amri (2014) state that in instructional design there are 4 activities carried out, namely 1) identifying initial abilities, 2) formulating learning objectives, 3) organizing the contents of the field of study and 4) conducting a feasibility study. The three variables are condition variables, method variables and learning outcome variables. Thus instructional design (learning) is all activities carried out by the teacher in an effort to 
understand students about the subject matter they teach. These activities include lesson planning, analysis of subject matter, methods and evaluation. Learning design also means how scientific theories that contain concepts can be applied by students in real forms. Learning design also means how students can apply affective (moral) values in themselves so that they can become their daily characteristics and characters. Therefore, instructional design is needed by the teacher so that the presentation of learning material is successful. With the learning design, every activity carried out by the teacher has been planned and the teacher will find it easier to carry out. Thus the learning design will function as a guide and control tool whether a final goal of learning has been achieved or not.

Natural Sciences (IPA) is a subject that deals with how to find out about nature systematically, so that Science is not only the mastery of a collection of knowledge in the form of facts, concepts, or principles but is also a process of discovery. Science education is expected to be a vehicle for students to learn about themselves and the natural surroundings, as well as the prospect of further development in applying it in everyday life. The learning process emphasizes providing direct experience to develop competencies in order to explore and understand the natural surroundings scientifically. Science education is directed to inquiry and act so that it can help students to gain a deeper understanding of the natural surroundings.

Since the last decade, the character of education has become an important issue (Pradana et al, 2020). The world of education which is the mouthpiece for the advancement of a country must follow and adapt to the progress of the era (Ainsyiyah \& Ginting, 2020). The Ministry of National Education (2008) revealed that the Subject Teacher Meeting (MGMP) is a forum for professional activities for teachers of the same subject at the SMP/MTs/SMPLB, SMA/MA/SMALB, and SMK/MAK levels at the district/city level which consists of a number of teachers from a number of schools. Thus the Subject Teacher Deliberation (MGMP) is an association or association for subject teachers who are in a school/madrasah, district/city which functions as a means of communicating, learning, and exchanging thoughts and experiences in order to improve teacher performance. In the Subject Teacher Deliberation (MGMP) forum, problems encountered in the teaching field are resolved, such as the application of a learning model, the use of media, teaching methods, learning design and teaching evaluation. Empowerment of Subject Teacher Deliberation (MGMP) efforts are made to make the Subject Teacher Deliberation (MGMP) effective to improve the quality and skills of teachers. With the empowerment of MGMP expected can function in improving the quality of educators (teachers) in providing learning in madrasah. The empowerment that is done is by guiding the teacher in designing a lesson using two methods, namely the method of creating and the method of imitating. The method of creating is a method of guiding teachers about learning design where the teacher is asked to design learning designs based on the creativity of the teacher himself (creating new designs). While the imitation method is a method of guiding teachers about learning design where the teacher is asked to imitate the learning designs that have been provided.

As the objective conditions that occur, the author has encountered the problem that during the coaching and supervision that the author did, there were many teachersScience subjects in their Learning Implementation Plan (RPP) imitated their peers from other regions (copy and paste). Then in teaching there is also no learning design from the science subject teacher. The teacher only uses the old pattern (traditional) which has not changed from the previous years. Therefore, it is very necessary to design a learning that can design science learning professionally, so that it can express all the benefits that exist in science subjects for students as developers of science and technology for the future. Based on these 
objective conditions, the authors are interested in conducting research with the title "Improving Teacher Skills in Designing Learning through Empowerment of MGMP and Achievement Motivation".

\section{Research Methods}

This research was conducted among public and private Madrasah Tsanawiyah science teachers in Pematangsiantar City. The research was conducted with an experimental research method. The treatment applied to the research subjects was the MTs science teachers in the form of guidance in designing learning by using imitating methods and methods of creating. The modeling method is carried out by providing an explanation through lectures, demonstrating it, setting certain criteria, selecting examples that can represent the material presented and making models to be imitated and assigning guidance participants (teachers) to imitate exactly as the model shown. The focus of this imitation method is that the tutor (resource person) provides a model for the guidance participants to imitate exactly as the model shown. Meanwhile, the method of creating is carried out by providing explanations through lectures, demonstrating them, establishing certain criteria and assigning guidance participants (teachers) to create their respective learning designs. As for the focus on the creative method, the participants of proper guidance are not tutors or resource persons.

This study uses a $2 \times 2$ factorial design. This design will compare the influence of the guidance method on designing learning used for MTs science teachers. Both methods of guidance are applied to the achievement motivation group. The teacher guidance method consists of two methods, namely the method of creating and the method of imitating. The teacher guidance method is the independent variable and the teacher's ability to design learning as the dependent variable and achievement motivation as the intervention variable. Achievement motivation can be divided into high achievement motivation and low achievement motivation. The number of teachers studied was 24 people. Of the 24 people, 12 were determined to have high achievement motivation and 12 people who had low achievement motivation. Then from each group the achievement motivation was further divided into two groups and each group was guided by the method of creating and imitating methods. Thus the division of the research group is as in this table:

Table 1. Research Group

\begin{tabular}{|c|c|c|}
\hline Group & Achievement Motivation and Treatment & Total number of teachers \\
\hline I & Height and Method of Creating & 6 \\
II & Height and Modeling Methods & 6 \\
III & Low and the Method of Creating & 6 \\
IV & Low and Exemplary Methods & 6 \\
\hline & Amount & 24 \\
\hline
\end{tabular}

The instrument in this study consisted of instruments to measure the skills of teachers in designing learning knowledge (theoretically) and the results of the design (practical) as well as achievement motivation instruments. For the instrument of teacher design skills in knowledge (theoretical) used knowledge instruments about learning design which refers to Mudhoffir's opinion about learning design, namely 1). Teaching objectives, 2). Procedures (activities) and learning resources and 3) expected learning outcomes (evaluation). Then the instrument to assess the learning design of the (practical) design of the teachers was used as an assessment instrument for the Teaching Professional Education (PPG) learning 
design of the Directorate General of Learning and Student Affairs, Ministry of Research, Technology and Higher Education 2017. The instrument for achievement motivation was developed in the form of a statement using the semantic differential technique. This Differential Semantic Technique is a technique of making statements in the form of a value scale that uses two different poles of properties, the two different properties are taken from the concept of questions made (Bloom, et al. 1971). While the indicators used to compile achievement motivation instruments are indicators of achievement motivation in accordance with the theory of human needs according to McCelland (Thoha: 1996), namely 1) likes to take moderate risks, 2) requires immediate feedback, 3) calculates success and 4) being attached to the task.

Before being used in instrument research, the construct validity is assessed first. To assess the validity of this construct, experts from the University of Simalungun, North Sumatra were asked. The instrument for which the construct validity was assessed was an instrument for assessing the (theoretical) knowledge of teachers about science learning design and achievement motivation instruments. Whereas the instrument for assessing the results of the design (practical) of the instructional design of teachers is no longer assessed for its validity because it is considered to have been tested considering that the instrument is an instrument used by the Teacher Professional Education (PPG) of the Directorate General of Learning and Student Affairs, Ministry of Research, Technology and Higher Education in 2017.

Furthermore, the stages carried out in this study, first is to measure the achievement motivation of the participating teachers. Based on the achievement motivation score, the teachers who have high and low achievement motivation are classified. Then provide treatment in the form of guidance on designing learning by using imitating methods and methods of creating to groups of teachers who have high and low achievement motivation. Then in the next stage, conduct an assessment of the learning design prepared by the teacher. The score for the skills of the teacher in designing learning is taken from the average score of the teacher's knowledge of the learning design and the score of the results of the design of the learning design of the teacher. The scores for the skills of the teachers in designing this lesson were compared and correlated with the achievement motivation of the teachers who participated in the training. The calculation of research data was carried out in the first stage, the scores for the skills of the teachers in designing learning obtained were measured for normality and homogeneity. Then the score of the skills of the teacher in designing the lesson by comparing the achievement motivation and the treatment that has been given, is calculated by the two-factor interaction ANOVA test (2-way ANOVA). The $t$ test was then performed to compare the results of each group being compared. All calculations in this study were carried out with the SPSS 23 Program (Santoso, 2016).

\section{Results and Discussion}

\subsection{Research Result}

From the research, the following results were obtained:

Table 2. Teacher Skills Scores in Designing Learning in the Four Research Groups

\begin{tabular}{|l|c|c|}
\hline \multirow{2}{*}{$\begin{array}{c}\text { Motivation } \\
\text { Achievers }\end{array}$} & \multicolumn{2}{|c|}{ Guidance Method } \\
\cline { 2 - 3 } High & Create & Imitate \\
\hline Low & $86,86,88,85,84,84$ & $80,86,84,80,80,84$ \\
\hline
\end{tabular}


Before calculating the overall data, the normality and homogeneity are first calculated. The calculation of normality was carried out using the Shapiro-Wilk and Kolmogorov-Smirnov test tools (the same as the Liliefors test), while the data homogeneity was carried out using the Levene test. To test for normality and homogeneity, the data taken is the score of teacher skills based on the method of guidance and achievement motivation. The calculations were performed using the IBM SPSS Statistics version 23 program. The results of the normality and homogeneity of the data are as shown in the following table:

Table 3. Data Normality Calculation Results Tests of Normality

\begin{tabular}{|l|l|l|r|r|r|r|r|}
\hline \multicolumn{2}{|l|}{$\begin{array}{l}\text { Research } \\
\text { Group }\end{array}$} & \multicolumn{1}{|c|}{$\begin{array}{c}\text { Kolmogorov- } \\
\text { Smirnova }\end{array}$} & \multicolumn{6}{|c|}{ Shapiro-Wilk } \\
\hline & & $\begin{array}{c}\text { Statisti } \\
\text { cs }\end{array}$ & df & \multicolumn{1}{c|}{ Sig. } & Statistics & df & \multicolumn{1}{c|}{ Sig. } \\
\hline Teacher & Motiv.Tng.Met.Made &, 204 & 6 &, $200 *$ &, 902 & 6 &, 389 \\
Skills in & Motiv.Tng.Met.Mencontoh &, 294 & 6 &, 114 &, 843 & 6 &, 138 \\
Designing & Motiv.Redh.Met. Create &, 310 & 6 &, 074 &, 805 & 6 &, 065 \\
Lessons & Motiv.Redh.Met. Examples &, 204 & 6 &, $200 *$ &, 902 & 6 &, 389 \\
\hline
\end{tabular}

*. This is a lower bound of the true significance.

a. Lilliefors Significance Correction

The test results with the two test tools obtained results with a probability (significance) above 0.05 , which means that the overall data to be analyzed is normally distributed.

Table 4. Data Homogeneity Calculation Results

Test of Homogeneity of Variance

\begin{tabular}{|c|c|c|c|c|c|c|}
\hline & $\begin{array}{l}\text { Levene } \\
\text { Statistics }\end{array}$ & df1 & df2 & \multicolumn{3}{|c|}{ Sig. } \\
\hline \multicolumn{3}{|c|}{ Based on Mean } & 2,953 & 3 & 20 &, 037 \\
\hline \multirow[t]{3}{*}{ Designing Lessons } & \multirow{2}{*}{\multicolumn{2}{|c|}{$\begin{array}{l}\text { Based on Median } \\
\text { Based on Median and with } \\
\text { adjusted df }\end{array}$}} & 1,439 & 3 & 20 & , 041 \\
\hline & & & 1,439 & 3 & 11,368 & , 042 \\
\hline & \multicolumn{2}{|c|}{$\begin{array}{l}\text { Based on the trimmed } \\
\text { mean }\end{array}$} & 2,897 & 3 & 20 &, 030 \\
\hline
\end{tabular}

The test results with the Levene Test obtained results with a probability (significance) below 0.05 , which means that the overall data to be analyzed is homogeneous.

From the results of the calculation of normality and homogeneity, the analysis requirements have been met because the data to be analyzed is normal and homogeneous. Then the 2-way ANAVA calculation is carried out and the following results are obtained: 
Table 5. Anava Calculation Table

Tests of Between-Subjects Effects

Dependent Variable: Teacher Skills in Designing Learning

\begin{tabular}{|l|r|r|r|r|r|}
\hline Source & $\begin{array}{c}\text { Type III Sum } \\
\text { of Squares }\end{array}$ & df & Mean Square & \multicolumn{1}{c|}{ F } & \multicolumn{1}{c|}{ Sig. } \\
\hline Corrected Model & $410,458 \mathrm{a}$ & 3 & 136,819 & 30,015 &, 000 \\
Intercept & 158925,375 & 1 & 158925,375 & 34864,799 &, 000 \\
Method & 210,042 & 1 & 210,042 & 46,079 &, 000 \\
Achievement & 155,042 & 1 & 155,042 & 34,013 &, 000 \\
motivation & & & & & \\
Method * & 45,375 & 1 & 45,375 & 9,954 &, 005 \\
Achievement & & & & & \\
Motivation & 91,167 & 20 & 4,558 & & \\
Error & 159427,000 & 24 & & & \\
Total & 501,625 & 23 & & & \\
\hline Corrected Total & & & & \\
\hline
\end{tabular}

a. $\mathrm{R}$ Squared $=, 818$ (Adjusted R Squared $=, 791$ )

Based on table 5 it can be concluded as follows:

1. The difference in the skills of teachers in designing science learning with the methods of creating and imitating methods.

From the ANAVA calculation results in the table it can be seen that the calculated $\mathrm{F}$ price for the method is 46.079 . It can be seen that the significance value obtained is 0.000 , which is smaller than the significance level of 0.05. Thus, Ho: the two methods groups are identical is rejected, and Ha: the two method groups are not identical and is accepted. If we look at the calculation results, the mean skill of the teacher in designing learning with the guidance of creating methods is 84.33 and the mean of the skill of the teacher in designing learning with the method of modeling guidance is 78.42.

2. Differences in the skills of teachers in designing science learning between teachers who have high achievement motivation and teachers who have low achievement motivation. From the ANAVA calculation results in the table, it can be seen that the calculated $F$ value for achievement motivation is 34.013. It can be seen that the significance value obtained is 0.000 , which is smaller than the significance level of 0.05 . Thus, Ho: the two groups of achievement motivation are identical, and Ha: the two groups of achievement motivation are not identically accepted. If it is seen from the calculation of the mean value of the skills of teachers in designing learning with high achievement motivation of 83, 92 and the mean of the final test of the skills of teachers of designing learning with low achievement motivation of 78.83 .

3. The interaction between the guidance method and achievement motivation.

From the ANAVA calculation results in the table, it can be seen that the calculated $F$ value for the interaction between the guidance method and achievement motivation is 9.954. While the significance value obtained is 0.005 smaller than the significance level of 0.05 . Thus Ho, who stated that there was no interaction between the guidance method and achievement motivation, was rejected, and $\mathrm{Ha}$, who stated that there was an interaction between the guidance method and the achievement motivation, was accepted. It means that the guidance method with achievement motivation both affects the skills of teachers in designing learning.

Furthermore, to calculate the difference in the scores of teachers' skills in designing learning in the four groups being compared, it was carried out by using the $t$ test and the results were obtained as follows: 
Table 6. Summary of the Compared Groups t-test Results

\begin{tabular}{|c|c|c|}
\hline Groups to be Compared & Don't count & $\mathrm{t}$ table (t (0.05) (21)) \\
\hline I with II & 3,919 & 2,080 \\
III with IV & 6,269 & 2,080 \\
\hline
\end{tabular}

Based on table 6, the results are:

1. The score of the skills of the teacher in designing learning between the high achievement motivation group taught by the creative method is different from the high achievement motivation group who was taught by the imitation method. The value of $t$ count $>\mathrm{t}$ table (3.919>2.08), with the mean score of teacher skills obtained 85.50> 83.17. This shows that in groups of teachers with high achievement motivation it is better to be guided by the creative method rather than the imitation method.

2. The score of the skills of the teacher in designing learning between the low achievement motivation group who was taught by the creative method was different from the low achievement motivation group who was taught by the imitation method. The value of $t$ count> $\mathrm{t}$ table $(6.269>2.080)$, with the mean score of teacher skills obtained 82.33> 74.50. This shows that in the group of teachers with low achievement motivation it is better to be given guidance by imitating methods rather than creating methods.

\subsection{Discussion}

Hypothesis testing results firstshows that the guidance in the MGMP uses the method of creating and using the method of imitating an effect on the skills of teachers in designing learning. In general, teachers who are guided by the method of creating the results of designing learning skills are higher than teachers who are guided by the imitation method. This is because the method of creating has linked existing responses with new responses so as to spur teacher creativity in learning design skills. Teachers in general are more motivated to look for new forms by seeing what is around them through the literature and experiences they have done. In the process of creating new forms, the method of creating uses a thought process of metaphor and analogy. Metaphor means the use of words instead of actual words, but various paintings based on similarities or comparisons. Metaphors form a relationship of similarity, a comparison of an object or idea with other objects or ideas or using a combination of both. Through this combination, a creative process will occur, namely by connecting something that is mediocre with something that is unusual or strange. Or create a new idea from an idea that is mediocre. Whereas analogy is the equation or adjustment of the situation. Furthermore, in the process of thinking, analogy will remember something again (reproduction) because of the conformity or similarity with what has been seen and experienced. The relationship between these two responses is an association relationship on the basis of analogy. Thus the process of thinking metaphor and analogy is the correspondence of a situation in a figurative form that describes unique, strange and new things based on similarities or comparisons to the responses that have been experienced. In turn, this causes the learning design to be made richer in innovation and better than that which is guided by the imitation method.

This is in accordance with the results of research by Rochmawati (2019) which examines the management of multiple skills training for vocational teachers, who get the results that with the in-on-in model learning strategy. In first, it means that learning is carried out in an institution by providing material for a certain period of time. Then the on stage is carried out in each school for each participant supervised by the principal and appointed mentor. Then the second in was carried out at PPPPTK BOE Malang by using 
a scientific approach strategy with learning based on problems, projects and designs. It turned out to give good results for the dual skills of the trainees. This is because when participants are given a problem to solve, the elements of their creativity will appear when solving the problem. Then when given a task (project) that must be done, this creativity can be implemented in the form of activities that are useful for completing the task (project) given to them. Then they are able to design other problems and tasks to be solved together. The whole thing can stimulate the creativity of the training participants, so that their various skills increase. Then the research of Mardiningsih, L. and Djukri (2015) which states that the professionalism of science teachers increases with the optimization of lesson study activities. Because in Lesson Study activities, a collaborative process is carried out in which a group of teachers identifies a learning problem, designs a learning scenario, teaches students according to the scenario, evaluates and revises the learning scenario, re-learning with improved scenarios and conducting an evaluation process. The stages carried out in the lesson study are similar to the creative method that uses metaphorical thinking processes and analogies. When the teacher identifies a learning problem, there is a repetition of various learning problems that have existed in the teacher which then gives birth to creative ideas for solving them (metaphors). Furthermore, these ideas are manifested in the form of actions (solutions) to overcome learning problems and finally in the form of designs and learning scenarios that are better than before.

Also Asmiyati's (2018) research which examines increasing the competence of Islamic Education teachers in compiling scientific-based lesson plans which states that Islamic education teachers who are given workshop guidance with a scientific approach have an increase in the competence of preparing lesson plans. After two cycles, the practice of Islamic education teachers' ability in preparing lesson plans was increasing and the resulting lesson plans were getting better. Because scientific learning adopts scientific steps in building science based on scientific methods. The stages carried out in the scientific approach process are observing. Training participants make observations on problems related to lesson plans in the form of facts, concepts and procedures. Then the second stage is the training participants ask questions about the things that have been observed earlier. These two stages are metaphorical thought processes. Then in the third stage the training participants try to compile the lesson plan based on the observations and deepening of the material (questions) they have done. Then in the fourth stage the training participants connect the lesson plans they have compiled with the development of science that is developing according to the subjects they are teaching. At this stage the participants carry out an analogy thinking process. Thus the application of the training model with a scientific approach invites training participants to discover new knowledge and skills that they do not yet have. The stages that must be passed in this scientific approach are the same as the method of creating. With the method of creating teachers can improve their ability to design the learning to be taught.

The results of testing the second hypothesis indicate that achievement motivation affects the skills of teachers in designing learning. Motivation is a psychological condition that encourages a person to meet their needs. In addition, motivation is also a hidden power in a person that will encourage him to act in a certain way. Meanwhile, achievement motivation is an impetus that arises in a person to work so as to produce a work that is of higher quality than the work of others (achievement). If achievement motivation arises in a person, he will try to show better performance results than other people in his profession. Therefore, achievement motivation has an influence (relationship) with the skills of a teacher in designing learning. If the motivation for 
achievement is high (good) then the skills of a teacher in designing learning are also good, on the other hand, if the motivation for achievement is low (not good) then the skills of a teacher in designing learning will also be less good. This is in accordance with the results of research by Arismunandar, Y. (2016) which states that work motivation has an effect on teacher performance. The higher the work motivation of a teacher, the higher the teacher's performance. Conversely, if the lower the work motivation of a teacher, the performance will also decrease. Also Andari's research (2015) states that the teacher work motivation variable has a significant effect on teacher performance. The magnitude of the correlation coefficient (r) between work motivation and teacher performance is 0 , 563 means that work motivation and teacher performance have a positive correlation, and the coefficient of determination ( $\mathrm{r} 2)$ is 0.317 , which means that work motivation contributes $31.7 \%$ to teacher performance and the remaining $68.3 \%$ is influenced by other variables. Sukamto's research (2016) also states that work motivation has a positive and significant effect on teacher performance if teacher work motivation increases, teacher performance will increase, and vice versa if teacher work motivation decreases, teacher performance will also decrease. The efficiency of work motivation is 0.262 , meaning that if the teacher's work motivation increases by $1 \%$, the teacher's performance also increases by $26.2 \%$, but what if the work motivation is reduced by one unit then the teacher's performance will decrease by $262 \%$. Achievement motivation is included in the category of work motivation. From the explanation of Siagian (2006) that the motivation of an employee is very much influenced by various factors, both internal and external. Including internal factors is a person's perception of himself, self-esteem, personal expectations, needs, desires, job satisfaction and the resulting work performance.

The results of testing the third hypothesis indicate that there is an interaction between the empowerment of the MGMP (method of guidance for teachers) and achievement motivation on the skills of teachers in designing learning. This is because instructional design is the entire process of analyzing learning needs and goals, development and delivery systems tailored to teaching needs and includes developing instructional materials and activities, testing them, revising all activities and learning outcomes. The entire learning needs analysis process is outlined in a design from the beginning to the end of the learning process, that is what is called learning design. Every teacher is very necessary to have the skills to design learning well. Meanwhile, achievement motivation is an encouragement to do something well in accordance with the goals outlined to get recognition (achievement) from others. Everyone has a different motivation for achievement from other people. Likewise, teachers will have different motivations from other teachers even though they teach the same subjects. One of the factors that influence achievement motivation is the knowledge and skills possessed. If someone has good knowledge and skills, they tend to have high achievement motivation. Conversely, if someone has low knowledge and skills, they tend to have low achievement motivation as well.

It can be explained that by using the method of creating, the motivational group of high achievers is more honed with their imagination to produce something new. In the process of creating new forms, the method of creating uses a thought process of metaphor and analogy. Thus, someone who has high achievement motivation has a strong impetus from within himself to produce something new (creation) that has more value than what has been there before. Therefore, the method of creating is more suitable to use and more acceptable because the creative power will be more stimulated. Then the second result shows that for groups of teachers who have low achievement motivation it is better to use the imitation method than the creating method. It is explained that learning by imitating 
what is meant here is based on the principle of the stimulation-response relationship in the instrumental learning process. The essence of the instrumental learning process is that the response is a tool (instrument) in achieving goals (Walker, 1975). Copying is a longlasting response if good reinforcement is received. Reinforcement can be in the form of a compliment or a gift that is not visible and then with this praise it is hoped that conditioning will occur. Conditioning is a form of learning in which the ability to respond to certain stimuli can be transferred to other stimuli. Conversely, someone who has low achievement motivation will not feel challenged to produce something new. The existing desire to follow dominates in him more. Guidance by imitating method is more in accordance with the character which tends to produce something that has been made by other people.

Therefore, the guidance given to teachers in the MGMP will increase their achievement motivation, by increasing the achievement motivation of the teachers, it will increase their knowledge and skills in designing learning. Thus, between the empowerment of the MGMP in the form of guidance provided to teachers in an integrated Science Subject Teacher Conference (MGMP) and achievement motivation will interact in influencing the skills of teachers in designing learning.This is in accordance with what Uno, HB (2015) said, however, that instructional design has an effect on the ease of learning. Thus teachers who are given material on instructional design have gained some of the basic knowledge needed, with this basic knowledge making it easier for them to master the material that the teacher will present. Also in line with the research results of Suprijanto, E. and Arikunto, S. (2016) which examined the effectiveness of the management of teacher working group (KKG) activities in terms of, a) participant components, b) development components, c) material components, d) components activities and e) infrastructure components. He got the results that to see the effectiveness of an institution such as KKG, MGMP, KKKS and KKPS, it can be examined from these 5 (five) components. If these five components are running properly, the effectiveness of the institution will be good. Conversely, if this component is not running or one component is missing so that it is incomplete, the effectiveness of the institution will not be obtained as expected. The results of research by Sopiyana, M. and Sugiyono (2015) show that MGMP can increase the ability and proficiency of teachers in carrying out teaching and learning activities (KBM). In the MGMP, subject matters are often discussed which teachers feel are difficult to teach. It was even continued with holding workshops to overcome teachers' difficulties with the material, so that the teacher's ability to teach it (designing the lesson) increased.

Then the research results of Suryana, Ayu Aryani and Irsyadunnas (2017) show that training to improve learning design is very relevant, especially regarding learning strategies and curriculum improvement, providing provisions for new teaching staff who are not familiar with pedagogy. In the learning design, there are steps that must be taken in teaching. The design also contains learning models and strategies that will be taken by a lecturer (teaching staff). Then what is really needed in empowering the MGMP is the role of the supervisor. As outlined that the role of supervisors in general is to help teachers and education leaders (school principals) to make wise decisions that affect the success of children's education. Supervisors have a strategic function in improving the quality of education with the task of guiding, fostering, monitoring, academic and managerial supervision, evaluating, making reports and following up on the results of academic and managerial supervision. Iskandar, D. (2016) in his research on the role of supervisors in improving the quality of education stated that one of the supervisor's roles is to carry out coaching, monitoring, performance appraisal and evaluating the 
implementation of school programs to improve the quality of education. In the implementation of coaching, the targets are teachers and school principals. In the implementation of monitoring carried out by supervisors is to monitor the existence of eight national education standards. In the performance appraisal, supervisors assess the performance of teachers and school principals. And in evaluating the implementation of the program, supervisors evaluate the implementation of all educational and teaching activities at their target schools. Thus empowering MGMP is one of the supervisor's subtasks, namely providing guidance to teachers. MGMP is a forum for guidance for teachers by supervisors. Therefore, the role of supervisors in empowering and advancing MGMP is very strategic.

\section{Conclusion}

Empowerment of the IPA MGMP really needs to be done. This empowerment is carried out by providing guidance on the skills of teachers in designing learning. Guidance is provided using the creation method and the imitation method. Besides that, the teachers' achievement motivation also needs to be measured. From the research results, it turns out that the guidance method used has an effect on the skills of science teachers in designing learning. By using the creating method, it turns out that the skill score of the teacher in designing learning is higher than using the imitation method. Achievement motivation also affects the skills of science teachers in designing learning. The group of teachers who had high achievement motivation had a higher score for designing science learning skills than the group of teachers who had low achievement motivation. Thus, in providing guidance to teachers, the achievement motivation of the teachers should first be measured. And also the method used should be a method that can increase teacher creativity in designing learning.

\section{References}

Ainsyiyah, E. D., Ginting, A. M. (2020). Pancasila and Civic Education Learning by Non Pancasila and Civic Education Program Graduate. Budapest International Research and Critics Institute-Journal (BIRCI-Journal), Vol 3, No 3, Page: 1650-1659.

Andari, S. (2015). Kontribusi Manajemen Kepala Sekolah, Motivasi Kerja Guru, dan Iklim Organisasi Terhadap Kinerja Kepala Sekolah Dasar, Jurnal Penelitian Ilmu $\begin{array}{llll}\text { Pendidikan } & 8(2), & \text { UNY } & \text { Yogyakarta. }\end{array}$ https://journal.uny.ac.id/index.php/jpip/article/view/8276/6910

Arismunandar, Y. (2016). Pengaruh Sertifikasi, Iklim Kerja Dan Motivasi Kerja Terhadap Kinerja Guru Di SD Negeri Kabupaten Lampung Selatan, Tesis, Universitas Lampung.

Asmiyati. (2018). Peningkatan Kompetensi Guru PAI Dalam Menyusun RPP Berbasis Saintifik di SD Piyungan Bantul TA 2016/2017, Jurnal Pendidikan Agama Islam 15 (2), Jurusan PAI UIN Sunan Kalijaga Yogyakarta. https://doi.org/10.14421/jpai.2018.152-02

Bloom. Benjamin S. et al. (1952). Taxonomi of educational objective: The clasification of educational goals, Handbook I: Cognitive Domain, New york: Logman Inc.

Depdiknas. (2004). Pedoman Musyawarah Guru Mata Pelajaran. Jakarta: Depdiknas.

Depdiknas. (2008). Standar Operasional Penyelenggaraan KKG MGMP. Jakarta : Depdiknas.

Iskandar, D. dan Wibowo, U.B. (2016). Peran Pengawas Pendidikan Dalam Meningkatkan Mutu Pendidikan SMP di Kabupaten Bima Provinsi Nusa Tenggara 
Barat, Jurnal Penelitian Ilmu Pendidikan 9 (2), UNY Yogyakarta. https://journal.uny.ac.id/index.php/jpip/article/view/12918/9050

Mardiningsih, L. dan Djukri (2015). Upaya Meningkatkan Profesionalisme Guru IPA di Kecamatan Sleman Melalui Optimalisasi Kegiatan Lesson Study, Jurnal Akuntabilitas Manajemen Pendidikan 3 (2), UNY Yogyakarta. https://doi.org/10.21831/amp.v3i2.6338

Pradana, D. A., et al. (2020). Nasionalism: Character Education Orientation in Learning Development. Budapest International Research and Critics Institute-Journal (BIRCI-Journal), Vol 3, No 4, Page: 4026-4034.

Rahman, M. dan Amri, S. (2014). Model Pembelajaran ARIAS Terintegratif Dalam Teori dan Praktik Untuk Menunjang Penerapan Kurikulum 2013, Jakarta : Prestasi Pustaka

Rochmawati. (2019). Manajemen Pendidikan dan Pelatihan Keahlian Ganda Guru Sekolah Menengah Kejuruan, Jurnal Administrasi dan Manajemen Pendidikan $\begin{array}{lllll}\text { (JAMP) } & 2 & \text { (3), } & \text { Universitas } & \text { Negeri }\end{array}$ http://journal2.um.ac.id/index.php/jamp/article/view/9292/4359

Samsudin, S. (2006). Manajemen Sumber Daya, Bandung : Pustaka Setia.

Santoso, S. (2016). Panduan Lengkap SPSS Versi 23, Jakarta : PT Elex Media Komputindo

Sedarmayanti. (2016). Manajemen Sumber Daya Manusia Reformasi Birokrasi dan Manajemen Pegawai Negeri Sipil, Bandung: PT. Revika Aditama.

Setyaningrum, Y. dan Husamah. (2013). Desain Pembelajaran Berbasis Pencapaian Kompetensi Panduan Merancang Pembelajaran Untuk Mendukung Implementasi Kurikulum 2013, Jakarta : Prestasi Pustaka

Siagian, S.P. (2006). Manajemen Sumber Daya Manusia, Jakarta : Bumi Aksara.

Sopiyana, M. Dan Sugiyono (2015). Efektivitas Kinerja Musyawarah Guru Mata Pelajaran (MGMP) Ekonomi SMA di Kabupaten Boyolali, Jurnal Akuntabilitas $\begin{array}{llll}\text { Manajemen } & \text { Pendidikan } & \end{array}$ (2), UNY https://doi.org/10.21831/amp.v3i2.6340

Sukamto, Y. (2016). Pengaruh Kompetensi Guru, Komitmen Kerja dan Motivasi Kerja Terhadap Kinerja Guru SMP Andalan di Sleman, Jurnal Penelitian Ilmu Pendidikan 9 (2), UNY Yogyakarta. https://journal.uny.ac.id/index.php/jpip/article/view/12917/9049

Suprijanto, E. dan Arikunto, S. (2016). Efektivitas Pengelolaan Kegiatan Kelompok Kerja Guru $(K K G)$ di Kecamatan Rembang Kabupaten Purbalingga, Jurnal Penelitian Ilmu $\begin{array}{llll}\text { Pendidikan } & 9 & (2), & \text { UNY }\end{array}$ https://journal.uny.ac.id/index.php/jpip/article/view/12914/9047

Suryana, Y., Ayu Aryani, S., Irsyadunnas. (2017). Impact Workshop Desain Pembelajaran oleh Center for Teaching Staff Development (CTSD) Terhadap Peningkatan Profesionalisme Dosen, Jurnal Akuntabilitas Manajemen Pendidikan 5 (1), UNY Yogyakarta. https://doi.org/10.21831/amp.v5i1.13117

Sutrisno, E. (2009). Manajemen Sumber Daya, Jakarta : Prenamedia

Thoha, M. (1996). Perilaku Organisasi, Jakarta : Rajawali.

Walker, Edward L. (1975). Conditioning dan Proses Belajar Instrumental, Terjemahan, Jakarta : Universitas Indonesia. 